\title{
SISTEM PENGENDALIAN INTERNAL PERSEDIAAN BAHAN HABIS PAKAI (STUDI KASUS : PT INDOKOM SAMUDRA PERSADA)
}

\author{
Addin Aditya $^{1)}$, Septi Oktafia Efendi ${ }^{2)}$, Fikri Hamidy ${ }^{3)}$ \\ 1) Sistem Informasi, STIKI Malang \\ ${ }^{2), 3)}$ Sistem Informasi Akuntansi, Universitas Teknokrat Indonesia \\ Jl. H.ZA Pagaralam, No 9-11, Labuhanratu,Bandarlampung \\ Email : addinaditya@gmail.com ${ }^{1)}$, septiokta@gmail.com ${ }^{2}$, fikrihamidy@gmail.com ${ }^{3)}$
}

\begin{abstract}
Abstrak
PT Indokom berdiri sejak tahun 1996 yang terdiri dari cabang PT Indokom Citra Persada, PT Indokom Samudra Persada, dan PT Indo American Seafood. PT Indokom Samudra Persada bergerak dalam bidang pengolahan pembekuan udang sejak tahun 2001 sampai sekarang. Dimana dalam proses pencatatan persediaan barang di logistik masih menggunakan lembar kerja spreadsheet, meskipun hasilnya sudah cukup baik namun dalam pengerjaannya masih memiliki beberapa kelemahan diantaranya dalam perhitungan biaya untuk penerimaan dan pengeluaran barang yang harus dihitung menggunakan rumus dilembar kerja spreadsheet. Dalam mengembangkan sistem penulis menggunakan metode pendekatan berorientasi objek yaitu metode waterfall, untuk metode pengembangan menggunakan metode pendekatan berorientasi objek dengan beberapa alat bantu dan teknik pengerjaan menggunakan UML yang terdiri dari use case, activity, class diagram, dan sequence. Bahasa pemograman yang digunakan adalah java dan database yang digunakan adalah MySQL. Tujuan dengan dibangunnya sistem pengendalian internal dapat membantu dalam mengontrol persediaan bahan habis pakai sehingga tidak terjadi kekurangan stok barang saat departemen lain membutuhkan barang tersebut. Hasil dari penelitian ini adalah sebuah sistem pengendalian internal yang dapat membantu dalam penginputan data, pencarian data serta membantu untuk mengetahui jumlah stok minimal.
\end{abstract}

Kata kunci: barang, internal, pengendalian, persediaan, sistem.

\section{Pendahuluan}

Pada umumnya perusahaan yang akan melakukan pencapaian tujuan berusaha untuk meningkatkan efektivitas dan efisiensi kerjanya, perusahaan mempunyai strategi-strategi tertentu yang telah ditetapkan. Salah satu strategi yang digunakan adalah sistem akuntansi persediaan. Sistem akuntansi persediaan merupakan salah satu bentuk untuk menekan biaya yang digunakan perusahaan. Salah satu sumber daya di dalam perusahaan yang harus menganut sistem informasi akuntansi yang baik adalah persediaan (Endrawati et al., 2015). Persediaan memiliki peranan yang penting yaitu sebagai sumber daya ekonomi fisik yang perlu diadakan dan dipelihara untuk menunjang proses (Baramuli \& Pangemanan, 2015). Perusahaan harus bisa menyusun daftar bahan baku, baik yang akan dilakukan pembelian maupun yang akan dilakukan pengolahan, selain itu apakah persediaan bahan baku tersebut dalam kondisi baik dan layak untuk diolah menjadi barang jadi (Febriyanti et al., 2017). Pengendalian internal atas persediaan seharusnya dimulai pada saat barang diterima (yang dibeli dari pemasok) untuk memastikan bahwa barang yang diterima sesuai dengan apa yang dipesan, maka setiap laporan penerimaan harus dicocokkan dengan formulir pesanan pembelian yang asli. Harga barang yang dipesan, seperti yang tertera dalam formulir pesanan pembelian seharusnya dicocokkan dengan harga yang tercantum dalam faktur tagihan (invoice).

Pengendalian internal yang baik merupakan faktor kunci pengelolaan organisasi yang efektif, karena pengendalian internal melibatkan penataan tanggung jawab dalam organisasi (Tandri et al., 2015). Tujuan pengendalian internal atas persediaan adalah untuk memastikan bahwa persediaan diamankan dan dilaporkan secara benar dalam laporan keuangan. Pengendalian internal akan menjadi early warning yang efektif bagi institusi atas indikasi terjadinya mismanagement atau penyimpangan karena posisinya langsung bersinggungan dengan tubuh institusi keseluruhan (Zamzami \& Faiz, 2015). Terdapat dua metode yang dapat digunakan dalam hubungannya dengan pencatatan persediaan yaitu Metode Fisik dan Metode Buku (Perpetual) (Baridwan, 2004). Penggunaan metode fisik mengharuskan adanya perhitungan barang yang masih ada pada tanggal penyusunan laporan keuangan. Prosedur pengeluaran bahan habis pakai belum menggunakan metode FIFO (First In First Out). Selain itu terdapat metode dalam penilaian persedian, salah satunya adalah metode First In First Out (FIFO). Metode FIFO merupakan metode penilaian persediaan yang berarti barang yang pertama kali masuk itulah yang pertama kali dicatat sebagai barang yang akan dikeluarkan dari gudang (Apriliani et al., 2013). FIFO dapat dianggap sebagai sebuah pendekatan yang logis dan realitas terhadap arus biaya ketika penggunaan metode identifikasi khusus adalah tidak memungkinkan atau tidak praktis (Anwar \& Karamoy, 2014). 
Pengelolaan data persediaan bahan habis pakai di PT Indokom Samudra Persada masih dilakukan secara manual baik untuk pencatatan permintaan barang, penerimaan bahan habis pakai, pengeluaran bahan habis pakai dan stok bahan habis pakai. Petugas memerlukan banyak waktu untuk mengumpulkan data dan file yang terpisah-pisah, dengan bahan habis pakai yang jenis dan jumlahnya banyak serta beragam. Sehingga laporan tentang kondisi persediaan menjadi lambat, laporan tersebut diperlukan manajemen untuk pengambilan keputusan dalam pengelolaan persediaan bahan habis pakai. Berdasarkan permasalahan di atas maka perlu adanya suatu sistem yang dapat digunakan untuk mengantisipasi minimumnya stok persediaan bahan habis pakai yaitu memperoleh proses pengembangan sistem persediaan menggunakan metode First In First Out (FIFO).

\section{Pembahasan}

\subsection{Perancangan Sistem}

Perancangan system bertujuan untuk memberikan gambaran apa yang seharusnya dikerjakan dan bagaimana tampilannya (Damayanti \& Sulistiani, 2017). Pada penelitian ini desain system digambarkan dengan Use Case Diagram. Use Case Diagram merupakan rancangan yang mendeskripsikan apa yang akan dilakukan oleh system (Rulyana \& Borman, 2014). Use case diagram atau diagram use case memodelkan prilaku (behaviour) sistem informasi yang akan dibuat (Melinda et al., 2017). Terdapat dua aktor yang menjalankan sistem yaitu Logistik dan Pimpinan. Dapat dilihat pada gambar bawah ini:

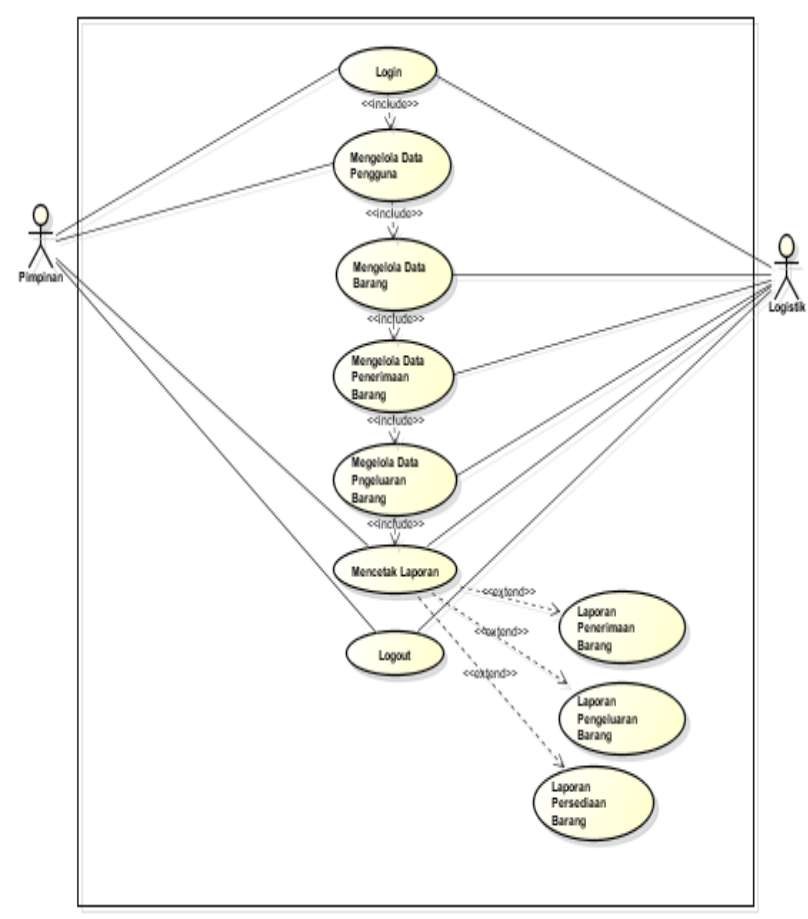

Gambar 1. Use Case Diagram Sistem Pengendalian Internal Persediaan Bahan Habis Pakai
Selanjutnya Tabel 1 berikut ini menjelaskan deskripsi use case diagram sistem pengendalian internal persediaan bahan habis pakai:

Tabel 1. Deskripsi Use Case Diagram Sistem Pengendalian Internal Persediaan Bahan Habis Pakai

\begin{tabular}{|c|c|c|}
\hline No. & $\begin{array}{c}\text { Use Case } \\
\text { Name }\end{array}$ & Deskripsi \\
\hline 1. & Login & $\begin{array}{l}\text { Merupakan proses untuk } \\
\text { melakukan login Logistik, dan } \\
\text { Pimpinan. }\end{array}$ \\
\hline 2. & Logout & $\begin{array}{l}\text { Merupakan proses untuk } \\
\text { melakukan Logout, Logistik } \\
\text { dan Pimpinan. }\end{array}$ \\
\hline 3. & $\begin{array}{l}\text { Mengelola } \\
\text { Barang }\end{array}$ & $\begin{array}{l}\text { Mengelola data Barang } \\
\text { merupakan proses generalisasi } \\
\text { yang meliputi lima buah } \\
\text { proses pengelolaan data } \\
\text { Barang yaitu Baru, Simpan, } \\
\text { Hapus, Batal, Edit dan Cari. }\end{array}$ \\
\hline 4. & $\begin{array}{l}\text { Mengelola } \\
\text { Penerimaan } \\
\text { Barang }\end{array}$ & $\begin{array}{l}\text { Mengelola data Penerimaan } \\
\text { Barang merupakan proses } \\
\text { generalisasi yang meliputi } \\
\text { lima buah proses pengelolaan } \\
\text { data Penerimaan Barang yaitu } \\
\text { Baru, Simpan, Hapus, Batal, } \\
\text { dan Cari, Cetak. }\end{array}$ \\
\hline 5. & $\begin{array}{l}\text { Mengelola } \\
\text { Pengeluaran } \\
\text { Barang }\end{array}$ & $\begin{array}{l}\text { Mengelola data Pengeluaran } \\
\text { merupakan proses generalisasi } \\
\text { yang meliputi lima buah } \\
\text { proses pengelolaan data } \\
\text { Pengeluaran yaitu Baru, } \\
\text { Simpan, Hapus, Batal, dan } \\
\text { Cari, Cetak. }\end{array}$ \\
\hline 6 & $\begin{array}{l}\text { Mengelola } \\
\text { Pengguna }\end{array}$ & $\begin{array}{l}\text { Mengelola data Pengguna } \\
\text { merupakan proses generalisasi } \\
\text { yang meliputi lima buah } \\
\text { proses pengelolaan data kelas } \\
\text { yaitu Baru, Simpan, Hapus, } \\
\text { Batal, Edit dan Cari. }\end{array}$ \\
\hline 7 & $\begin{array}{l}\text { Mencetak } \\
\text { Laporan }\end{array}$ & $\begin{array}{l}\text { Merupakan proses mencetak } \\
\text { data laporan ke dalam basis } \\
\text { data. }\end{array}$ \\
\hline
\end{tabular}

\subsection{Implementasi Program}

Menggunakan sistem merupakan tahap mengoperasikan sistem. Tahap penggunaan sistem ini dilakukan setelah 
sistem selesai, kemudian penulis melaksanakan pelatihan terhadap petugas yang akan menggunakan sistem, dengan memberi pengertian dan pengetahuan yang cukup tentang sistem informasi, posisi dan tugas setiap fungsi. Pelatihan ini untuk petugas yang akan mengoperasikan sistem, yaitu logistik. Hal ini dimaksudkan agar pengguna memahami prosedur kerja sistem, dapat mengurangi kesalahan-kesalahan yang timbul yang dapat menghambat kelancaran operasional perusahaan, sehingga tujuan sistem dapat tercapai.

Sistem yang dibangun diharapkan mempermudah logistik dalam membuat laporan penerimaan barang, laporan pengeluaran, laporan persediaan barang dan laporan stok minimum. Sistem dimulai dari form login, yang berfungsi untuk keamanan data di mana pimpinan, dan logistik diminta untuk memasukan nama pengguna, jabatan dan Password yang telah ditentukan sebelumnya.

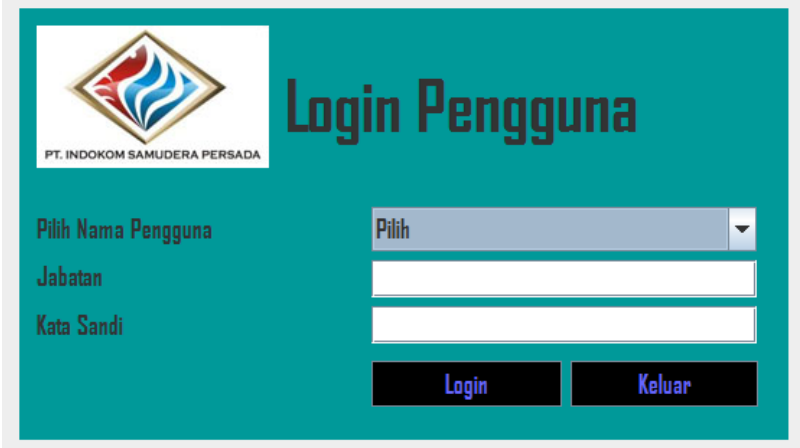

Gambar 2. Form Login Sistem Pengendalian Internal Persediaan Bahan Habis Pakai

Setelah login bagian logistik akan memasuki menu utama pada sistem pengendalian internal persediaan bahan habis pakai. Form Utama merupakan halaman utama yang terdiri dari Login, Pengguna, Data Barang, Data Pembelian, Data Pengeluaran, Laporan.

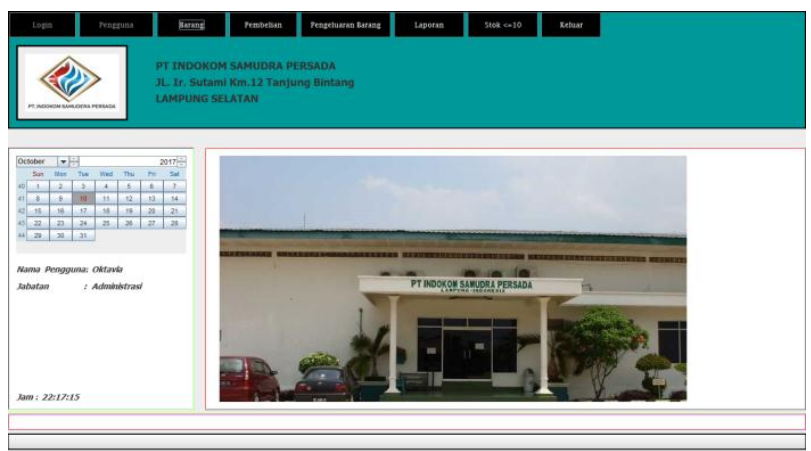

Gambar 3. Form Menu Utama Sistem Pengendalian Internal Persediaan Bahan Habis Pakai

Bagian logistik dapat mengelola barang pada form data barang. Form data barang merupakan form yang berisikan tentang data Barang. Form ini digunakan ketika akan menambah, mengubah, dan menghapus data Barang. Adapun data yang terdapat dalam Form Data Barang adalah Kode Barang, Nama Barang, Satuan, Harga, Masuk, keluar, Stok.

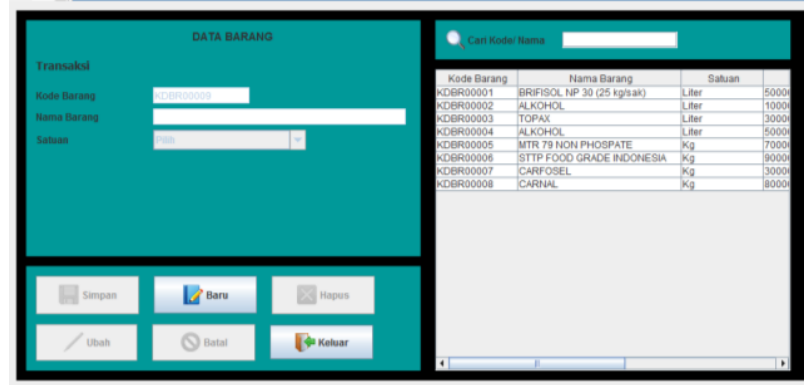

Gambar 4. Form Data Barang Sistem Pengendalian Internal Persediaan Bahan Habis Pakai

Untuk pengelolaan data pembelian bagian logistik dapat mengelolanya pada form data pembelian barang. Form ini merupakan form yang berisikan tentang data Pembelian Barang. Form ini digunakan ketika akan menambah, dan menghapus data Pembelian Barang. Adapun data yang terdapat dalam Form Data Pembelian Barang adalah Kode Beli, Tanggal, Keterangan, Kode Barang, Nama Barang, Satuan, Harga, Jumlah, Sub Total, Total .

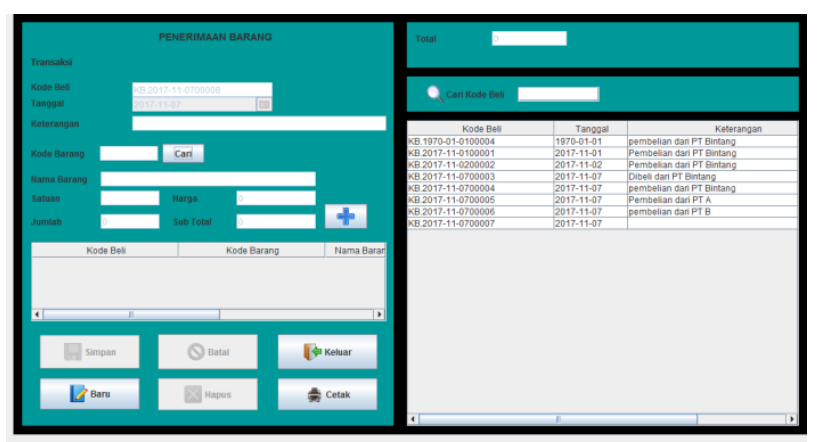

Gambar 5. Form Data Penerimaan Barang Sistem Pengendalian Internal Persediaan Bahan Habis Pakai

Kemudian, untuk pengelolaan pengeluaran barang bagian logistik dapat mengelola melalui form data pengeluaran barang. Form ini berisikan tentang data pengeluaran barang. Form ini digunakan ketika akan menambah, dan menghapus data Pengeluaran Barang. Adapun data yang terdapat dalam Form Data Pengeluaran Barang adalah No BAB, Tanggal, Keterangan, Kode Barang, Nama Barang, Satuan, Harga, Jumlah, Sub Total, Total.

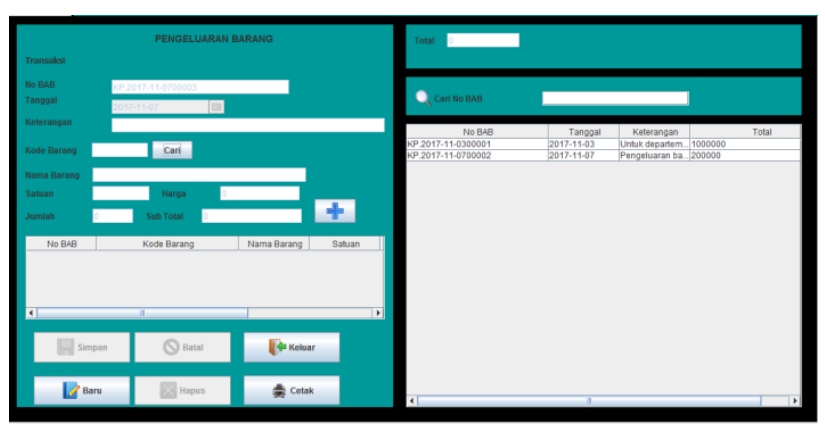

Gambar 6. Form Data Pengeluaran Barang Sistem Pengendalian Internal Persediaan Bahan Habis Pakai 
Untuk pengendalian persediaan barang pada sistem ini dilengkapi fitur stok minimum barang untuk pengendalian stok barang yang ada.

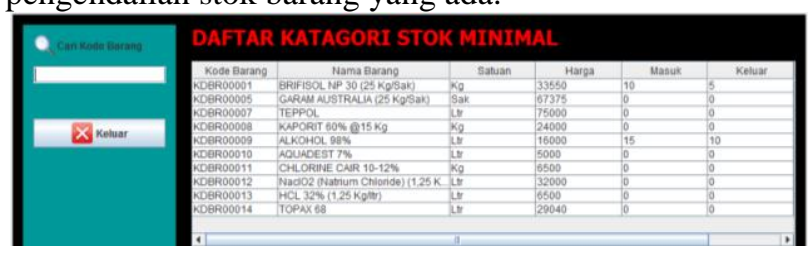

Gambar 6. Form Daftar Kategori Stok Minimal Sistem Pengendalian Internal Persediaan Bahan Habis Pakai

Laporan penyusutan disajikan sesuai dengan kaidah laporan penyusutan dengan menyajikan nilai perolehan, beban penyusutan dan nilai baku

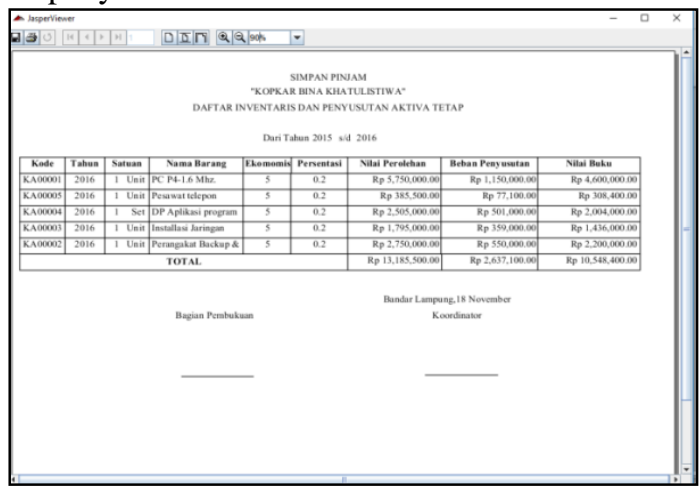

Gambar 5. Output Laporan Penyusutan

\section{Kesimpulan}

Berdasarkan pembahasan penelitian tentang Sistem Pengendalian Internal Persediaan Bahan Habis Pakai dapat diambil kesimpulan yaitu :

1. Sistem persediaan bahan habis pakai pada PT Indokom Samudra Persada dikembangkan menggunakan metode fifo. Melalui metode ini, stok barang yang pertama kali masuk akan dikeluarkan pada saat permintaan pengeluaran barang oleh departemen yang membutuhkan. Sisa stok barang akan terlihat secara otomatis melalui sistem yang dibangun ini.

2. Sistem yang dibangun akan menampilkan secara otomatis batas minimum stok barang yang harus dipesan, sehingga akan memudahkan sistem pengendalian internal persediaan bahan habis pakai

\section{Daftar Pustaka}

Anwar, N.F. \& Karamoy, H., 2014. Analisis Penerapan Metode Pencatatan Dan Penilaian Terhadap Persediaan Barang Menurut PSAK No.14 Pada PT. Tirta Investama DC Manado. Jurnal EMBA, 2(2).

Apriliani, R., Riyanto, A. \& Susilawati, 2013. Telaah Sistem Informasi Persediaan Obat Menggunakan Metode Fifo Pada Apotek Adya Sukabumi. In Simposium Nasional Ilmu Pengetahuan dan Teknologi (SIMNASIPTEK)., 2013.
Baramuli, F. \& Pangemanan, S.S., 2015. Analisis Sistem Informasi Akuntansi Persediaan Pada Yamaha Bima Motor Toli-Tol. Jurnal EMBA, 3(3).

Baridwan, Z., 2004. Intermediete Accounting. Yogyakarta: BPFE.

Damayanti \& Sulistiani, H., 2017. Sistem Informasi Pembayaran Biaya Sekolah Pada SD Ar-Raudah Bandar Lampung. Jurnal TEKNOINFO, 11(2).

Endrawati, Surya, F. \& Perta R., W.P., 2015. Perancangan Sistem Akuntansi Persediaan Dan Kartu Gudang Berbasis Komputer Pada Konveksi Tas. Jurnal Akuntansi \& Manajemen, 10(2).

Febriyanti, D.R., Dwiatmanto \& Azizah, D.F., 2017. Analisis Sistem Akuntansi Persediaan Bahan Baku Dalam Meningkatkan Pengendalian Intern ( Studi Kasus Pada CV. Cool Clean Malang). Jurnal Administrasi Bisnis (JAB), 44(1).

Melinda, M., Borman, R.I. \& Redy, E.S., 2017. Rancang Bangun Sistem Informasi Publik Berbasis Web (Studi Kasus : Desa Durian Kecamatan Padang Cermin Kabupaten Pesawaran). Jurnal TEKNO KOMPAK, 11(1).

Rulyana, D. \& Borman, R.I., 2014. Aplikasi Simulasi Tes Potensi Akademik Berbasis Mobile Platform Android. In Seminar Nasional FMIPA-Universitas Terbuka. DKI Jakarta, 2014.

Tandri, M., Sondakh, J.J. \& Sabijono, H., 2015. Efektivitas Penerapan Sistem Pengendalian Intern Terhadap Penerimaan Dan Pengeluaran Kas Di Rsu Pancaran Kasih Gmim Manado. Jurnal EMBA, 3(3).

Zamzami, F. \& Faiz, I.A., 2015. Evaluasi Implementasi Sistem Pengendalian Internal: Studi Kasus Pada Sebuah Perguruan Tinggi Negeri. Jurnal Akuntansi Multiparadigma (JAMAL), 6(1). 